\title{
Direct and Maternal Genetic Trends for Some Productive and Reproductive Traits in Egyptian Buffaloes
}

\author{
Abu El-Naser, IAM \\ Animal Production Department, Faculty of Agriculture, Damietta University, Egypt \\ E-mail: Atta19812000@yahoo.com
}

(received 14-11-2019; revised 14-02-2020; accepted 14-02-2020)

\begin{abstract}
ABSTRAK
Abu El-Naser, IAM. 2020. Kecenderungan gen langsung dan maternal beberapa sifat produksi dan reproduksi Kerbau Mesir. JITV 25(1): 1-10. DOI: http://dx.doi.org/10/14334/jitv.v25i1.2069.

Penelitian ini bertujuan untuk melihat kecenderungan fenotip genetik maternal dan genetik langsung pada sifat-sifat produksi seperti produksi susu pertama (FLMY, kg), masa laktasi pertama (FLP, hari), dan produksi susu harian laktasi pertama (FLMD, $\mathrm{kg}$ ) serta sifat reproduksi seperti umur pertama beranak (AFC, bulan), masa kosong pertama (FDO, hari) dan jarak beranak (FCI, hari). Data yang digunakan merupakan kumpulan data laktasi pertama selama 25 tahun (1991-2015) dari 1.104 ekor pejantan dan 482 indukan yang dipelihara di peternakan Mahallet Mousa milik Lembaga Penelitian Produksi Ternak. Data dianalisis dengan model ternak untuk menentukan parameter penelitian. Nilai tengah dari FLMY, FLP, FLDM, AFC, FDO dan FCI berturut-turut adalah 1.546,5kg; 189 hari; 7,9kg; 37,9 bulan; 120,8 hari dan 428 hari. Nilai heritabilitas langsung $\left(\mathrm{h}^{2} \mathrm{a}\right)$ untuk sifat yang sama secara berturut-turut adalah 0,$25 ; 0,18 ; 0,24 ; 0,45 ; 0,18$ dan 0,19 . Nilai heritabilitas maternal untuk sifat yang sama secara berturut-turut adalah 0,$12 ; 0,19 ; 0,22 ; 0,25 ; 0,12$ dan 0,12 . Hubungan genetik (rg) diantara sifat-sifat yang diteliti bervariasi antara $-0,19$ hingga 0,38 . Ketepatan variasi nilai pemuliaan yang diprediksikan adalah antara 69 hingga 94; 0,37 hingga 94 dan 42 hingga 91\% untuk FLMY, FLP, FLDM, AFC, FDO dan FCI pejantan, betina dan indukan secara berturut-turut yang mana menunjukkan bahwa pengayaan genetik dapat diaktualisasikan melalui masing-masing pejantan, betina dan indukan. Kecenderungan genetik maternal dan aditif, lingkungan dan fenotip tidak terlihat secara signifikan pada semua sifat. Hal ini mengindikasikan pentingnya penyusunan rencana untuk meningkatkan mutu genetik dan kondisi lingkungan karena mampu meningkatkan produktifitas dan keuntungan.
\end{abstract}

Kata Kunci: Kerbau, Kecenderungan Genetik Maternal dan Langsung, Kecenderungan Fenotip

\begin{abstract}
Abu El-Naser, IAM. 2020. Direct and maternal genetic trends for some productive and reproductive traits in Egyptian buffaloes. JITV 25(1): 1-10. DOI: http://dx.doi.org/10/14334/jitv.v25i1.2069.

This study was done to determine the direct and maternal genetic and phenotypic trends for productive traits such as first lactation milk yield (FLMY, kg), first lactation period (FLP, d) and first lactation daily milk (FLDM, $\mathrm{kg}$ ), and reproductive traits such as age at first calving (AFC, mo), First days open (FDO, d) and first calving interval (FCI, d). Data were collected over consecutive 25 years (1991 to 2015) of 1104 first lactation of 135 sires and 482 dams maintained at Mahallet Mousa farms of Animal Production Research Institute. Data were analyzed by Animal model to determine genetic parameters for studied traits. Means of FLMY, FLP, FLDM, AFC, FDO and FCI were $1546.5 \mathrm{~kg}, 189 \mathrm{~d}, 7.9 \mathrm{~kg}, 37.9 \mathrm{mo}, 120.8 \mathrm{~d}$ and $428 \mathrm{~d}$, respectively. The direct heritability $\left(\mathrm{h}^{2} \mathrm{a}\right)$ for same traits were $0.25,0.18,0.24,0.45,0.18$ and 0.19 , respectively. Corresponding maternal heritability $\left(\mathrm{h}^{2} \mathrm{~m}\right)$ for mentioned traits was $0.12,0.19,0.22,0.25,0.12$ and 0.12 , respectively. Genetic correlations $\left(\mathrm{r}_{\mathrm{g}}\right)$ among studied traits were varied between -0.19 to 0.38 . Accuracy of predicted breeding value varied between 69 to $94,0.37$ to 94 and 42 to $91 \%$ for FLMY, FLP, FLDM, AFC, FDO and FCI of sires, cows and dams, respectively that revealed the genetic improvement could be actualized through each of cows or sires or dams. Additive and maternal genetic, permanent environmental and phenotypic trends were not significant for all studied traits. It indicated that it is important to set up a plan to improve genetic and environmental conditions thus, increasing productivity and realization of high profitability.
\end{abstract}

Key Words: Buffaloes, Direct and Maternal Genetic Trends, Phenotypic Trends

\section{INTRODUCTION}

Milk is an important food considered the Egyptian buffaloes an important animal for milk production and meat in Egypt. The number of buffaloes is nearly about
3.9 million. Where contribution to milk production nearly $45.5 \%$ of total milk in Egypt (FAO 2013). Liu et al. (2008) shown that the genetic correlations between productive and reproductive traits were negative. To increase genetic and phenotypic improvement in 
Egyptian buffaloes for milk traits, constructed selection indices (Fooda et al. 2010). The annual genetic trend in the first three lactations in Egyptian buffaloes for total milk yield, lactation period, calving interval and days open were negative (Shalaby et al. 2016). The conception of genetic progress trend shall help in future genetic direction to be accepted by defining specific goals to breeding profitable and continuity of dairy herd (Missanjo et al. 2012). Genetic trends for milk yield and calving interval were significant and correspond to 1.57 $\mathrm{kg} / \mathrm{y}$ and $0.058 \mathrm{~d} / \mathrm{y}$, respectively and phenotypic trends were $27.74 \mathrm{~kg} / \mathrm{y}$ and $0.647 \mathrm{~d} / \mathrm{y}$, respectively (Ramos et al. 2006). Maternal effects in the analysis models desirable for selection of productive and reproductive traits to optimize hoped for best response over long run (El-Awady et al. 2016). Therefore, the aims of current work were to determine genetic parameters, direct and maternal genetic and phenotypic trends for FLMY, FLP, FLMD, AFC, FDO and FCI in Egyptian buffaloes.

\section{MATERIALS AND METHODS}

Data utilized in the present study were collected over consecutive 25 years (1991 to 2015) of 1104 first lactation of 135 sires and 482 dams maintained at Mahallet Mousa Experimental farms (Main Mahallet Mousa, El-Nataf El-Gaded and El-Nataf El-kadim), Animal Production Research Institute (APRI), Ministry of Agriculture. Traits in this study were divided into productive traits namely first lactation milk yield (FLMY, kg), first lactation period (FLP, d) and first lactation daily milk (FLDM, $\mathrm{kg}$ ), and productive traits namely: age at first calving (AFC, mo), First day open (FDO, d) and first calving interval (FCI, d). Egyptian buffaloes were living under the same system of feeding and management in the stations. Lactating animals were milked twice daily during the lactation period, and milk yield was recorded daily. The animals were fed on Egyptian clover (Trifolium Alexandrinum) during December to May with concentrate mixture and rice straw. During June to November, animals were fed on concentrate mixture, rice straw and a limited amount of clover hay or silage. The animal was feed according to their live weight, milk production, and pregnancy status. Water is available for buffaloes at all times of the day. Buffaloes were inseminated during heat after 60 days postpartum, while heifers were inseminated when attained $350 \mathrm{~kg}$ of live body weight or 18-24 months of age.

\section{Statistical Analysis}

Data were analyzed using MTDFREML program of Boldman et al. (1995) with the multiple models to determine genetic and phenotypic parameters for studied traits. As the following model was:

$$
\mathrm{Y}=\mathrm{X} \boldsymbol{\beta}+\mathrm{Za}+\mathrm{Mm}+\mathrm{Wpe}+\mathrm{e}
$$

Where:

$\mathrm{Y}, \beta, \mathrm{a}, \mathrm{m}$, pe and $\mathrm{e}=\mathrm{a}$ vector of observations, $\mathrm{a}$ vector of fixed effects ((Month and year of calving and farm), a vector of direct additive genetic effect, a vector of maternal genetic effect, a vector of permanent environmental effect and $\mathrm{e}=\mathrm{a}$ vector of residual effect, respectively. However, $\mathrm{X}, \mathrm{Z}, \mathrm{M}$ and $\mathrm{W}=$ are incidence matrices relating records to fixed, direct genetic, maternal genetic and permanent environmental effects, successively

MTDFREML was used to estimate the best linear unbiased perdition (BLUP) of predicted breeding values for all animals.

Genetic trends were obtained by estimation regression the means of predicted breeding values for traits studied on the year of birth as described by (Sahin et al. 2012). The annual phenotypic trend for traits was estimated with regression of least-square means on calving year. Graphs that indicted genetic and environmental trends were made by Microsoft Office Excel. The regression was estimated via SAS program of computer (SAS 2002)

\section{RESULTS AND DISCUSSION}

The present unadjusted means of FLMY, FLP, FLDM, AFC, FDO, and FCI were $1546.5 \mathrm{~kg}, 189 \mathrm{~d}$, $7.9 \mathrm{~kg}, 37.9 \mathrm{mo}, 120.8 \mathrm{~d}$ and $428 \mathrm{~d}$, respectively are given in Table 1. The current mean of FLMY was lower than that observed by Madad et al. (2013) being $2220.03 \mathrm{~kg}$ in Khuzestan buffaloes and higher than that observed by Shalaby et al. (2016) being $1057 \mathrm{~kg}$ in Egyptian buffaloes. The present FLP and FCI were shorter than (310.4d and 586.6d, respectively) found by Thiruvenkadan et al. (2014) in Murrah buffaloes. While the current means of FLP, FDO and FCI were longer than that reflected by Shalaby et al. (2016) in Egyptian buffaloes being $226 \mathrm{~d}, 224 \mathrm{~d}$, and 538d, respectively. The present mean of FLMY was lower than (1619.7kg) reversed by Thiruvenkadan et al. (2014) and contrarily for the present mean of FLDM was higher than (5.38 $\mathrm{kg}$ ) in Murrah buffaloes. While the current means of FMY, AFC and FCI were lower than that observed by Seno et al. (2010) in Murrah buffaloes.

Coefficients of variation for traits in this study were ranging $(22.9 \%$ to $71.10 \%)$ the immense $\mathrm{CV} \%$ value for FDO $(71.10 \%)$, which showed a huge variation between individual buffalo. The present value for $\mathrm{CV} \%$ for FMY, AFC and FCI was higher than that noticed by Seno et al. (2010) in Murrah buffaloes.

The direct heritability $\left(\mathrm{h}_{\mathrm{a}}^{2}\right)$ for FLMY, FLP, FLDM, $\mathrm{AFC}, \mathrm{FDO}$ and FCI were moderate $0.25,0.18,0.24$, 
Table 1. Means, standard deviation (SD) and coefficient of variation (CV\%) for first lactation milk yield (FLMY), first lactation period (FLP), first lactation daily milk (FLDM), age at first calving (AFC), first days open (FDO) and first calving interval (FCI) in Egyptian buffalo

\begin{tabular}{lccc}
\hline \hline Trait & Mean & SD & CV (\%) \\
\hline FLMY, kg & 1546.5 & 587.7 & 38 \\
FLP, d & 189 & 45.4 & 24 \\
FLDM, kg & 7.9 & 3.2 & 40.5 \\
AFC, mo & 37.9 & 8.7 & 22.9 \\
FDO, d & 120.8 & 85.9 & 71.1 \\
FCI, d & 428 & 103.4 & 24.2 \\
\hline
\end{tabular}

Table 2. Estimate of variance components and heritability for traits under research work

\begin{tabular}{|c|c|c|c|c|c|c|}
\hline \multirow{2}{*}{ Estimates } & \multicolumn{6}{|c|}{ Traits } \\
\hline & FLMY & FLP & FLDM & $\mathrm{AFC}$ & FDO & FCI \\
\hline$\sigma_{\mathrm{a}}^{2}$ & 9403.76 & 886.71 & 306.38 & 889.66 & 416.35 & 465.45 \\
\hline$\sigma_{\mathrm{m}}^{2}$ & 4521.33 & 929.05 & 280.85 & 490.41 & 277.09 & 293.87 \\
\hline$\sigma_{\mathrm{pe}}^{2}$ & 14295.31 & 1578.51 & 433.98 & 216.78 & 623.63 & 612.97 \\
\hline$\sigma_{\mathrm{e}}^{2}$ & 9429.07 & 1480.49 & 255.32 & 378.77 & 993.15 & 1079.62 \\
\hline$\sigma_{p}^{2}$ & 37612.69 & 4872.70 & 1276.17 & 1970.75 & 2309.64 & 2449.15 \\
\hline$\sigma_{\mathrm{am}}$ & -36.78 & -2.06 & -0.36 & -4.87 & -0.58 & -2.77 \\
\hline $\mathrm{r}_{\mathrm{am}}$ & -0.006 & -0.002 & -0.001 & -0.007 & -0.002 & -0.007 \\
\hline $\mathrm{h}_{\mathrm{a}}^{2}$ & 0.25 & 0.18 & 0.24 & 0.45 & 0.18 & 0.19 \\
\hline $\mathrm{h}_{\mathrm{m}}^{2}$ & 0.12 & 0.19 & 0.22 & 0.25 & 0.12 & 0.12 \\
\hline$c^{2}$ & 0.38 & 0.32 & 0.34 & 0.11 & 0.27 & 0.25 \\
\hline$e^{2}$ & 0.25 & 0.30 & 0.20 & 0.19 & 0.43 & 0.44 \\
\hline
\end{tabular}

$0.45,0.18$ and 0.19 , respectively. While the maternal heritability $\left(\mathrm{h}_{\mathrm{m}}^{2}\right)$ was moderate for FLP, FLDM and AFC being $0.19,0.22,0.25$, respectively, While $h^{2}$ for FLMY, FDO and FCI were slightly low and being 0.12 as illustrated in Table 2. In general, obtained low estimated $\mathrm{h}_{\mathrm{a}}{ }_{\mathrm{a}}$ for FLMY, FLP, FDO and FCI were 0.14, 0.17, 0.07 and 0.08, respectively in Egyptian buffaloes by Shalaby et al. (2016), Madad et al. (2013) for FLMY was 0.06 of Khuzestan buffaloes, Seno et al. (2010) for FLMY and AFC were 0.20 and 0.07 , respectively in Murrah buffaloes and Catillo et al. (2001) for AFC was 0.26 in Murrah buffaloes. As a matter of fact, the estimated permanent environmental ration ranged from 0.11 to 0.38 , close to the finding by El-Awady \& Abu El-Naser (2017) for MY, LP, DO and CI in Friesian cows. Estimated genetic correlations $\left(r_{g}\right)$ among all traits varied between -0.19 to 0.38 . The $r_{g}$ among FLMY, FLP, and FLDM were positive and varied from 0.10 to 0.38 , and the same thing goes for genetic correlations among AFC, FDO and FCI were positive, ranged from 0.03 to 0.24 , as shown in table (3). The current results similar to that obtained by Shalaby et al. (2016) in Egyptian buffaloes for $r_{g}$ between FLMY andFLP was positive but higher than (0.81) present result, as well $r_{\mathrm{g}}$ between FDO and FCI taken the same trend, was positive and higher than current estimation (0.99). Gupta et al. (2015) in Murrah buffalo found $r_{g}$ between AFC and all of FLMY, FLP and FCI were positive and being $0.18,0.11$ and 0.19 , respectively, while $r_{\mathrm{g}}$ between FLP and FCI was 0.59 and $r_{\mathrm{g}}$ between 
Table 3. Estimation correlations among traits understudy in Egyptian buffaloes

\begin{tabular}{lcccccc}
\hline \multirow{2}{*}{ Trait1 } & & \multicolumn{6}{c}{ Correlations } & \\
\cline { 2 - 7 } & Trait2 & $\mathrm{r}_{\mathrm{g}}$ & $\mathrm{r}_{\mathrm{p}}$ & $\mathrm{r}_{\mathrm{e}}$ & $\mathrm{r}_{\mathrm{pe}}$ & $\mathrm{r}_{\mathrm{m}}$ \\
\hline \multirow{4}{*}{ AFC } & FLMY & 0.13 & 0.02 & 0.01 & 0.17 & -0.14 \\
& FLP & 0.14 & 0.14 & 0.04 & 0.17 & 0.05 \\
& FLDM & 0.19 & -0.16 & -0.29 & 0.10 & -0.34 \\
& FCI & 0.22 & -0.14 & -0.13 & -0.56 & -0.12 \\
& FDO & 0.24 & -0.03 & 0.05 & -0.05 & 0.04 \\
FLMY & FLP & 0.38 & 0.01 & 0.10 & 0.01 & -0.22 \\
& FLDM & 0.37 & 0.01 & 0.19 & 0.01 & 0.01 \\
& FCI & -0.01 & -0.02 & 0.01 & -0.03 & -0.05 \\
FLP & FDO & -0.19 & -0.02 & 0.08 & -0.05 & 0.14 \\
& FLDM & 0.10 & -0.02 & 0.17 & 0.01 & -0.46 \\
FLDM & FCI & -0.04 & -0.17 & -0.01 & 0.02 & -0.50 \\
FCI & FDO & 0.11 & -0.05 & -0.03 & 0.07 & 0.36 \\
& FCI & -0.09 & -0.13 & -0.57 & -0.16 & 0.47 \\
\hline
\end{tabular}

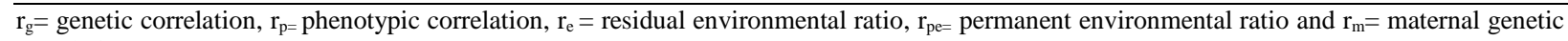
correlation.

FLMY and each of FLP and FCI were 0.86 and 0.49 , respectively.

The phenotypic correlations ranged from -0.17 to 0.19 among all traits (Table 3). The current study exceeded that observed by Shalaby et al. (2016) in Egyptian buffaloes, $r_{p}$ among FCI, FDO, FLMY and FLP were ranged from 0.166 to 0.931 . Maternal correlations among studied traits ranged from -50 to 0.46 , while the permanent environmental and residual ratios ranged from $-0.56-0.17$, and -0.57 to 0.17 , respectively (Table 3).

The portended breeding values (EBV's) through buffalo sires, buffalo cows and buffalo dams for FMY, FLP, FLDM, FDO and FCI are presented in Table 4. The breeding values for FMY, FLP, FLDM, FDO, and FCI of buffalo sires ranged from -444.73 to $397.84 \mathrm{~kg}$, 27.52 to $70.07 \mathrm{~d},-3.78$ to $3.74 \mathrm{~kg},-10.06$ to $13.76 \mathrm{mo}$, 44.54 to 46.69 and -35.77 to $46.40 \mathrm{~d}$, respectively. The corresponding value for buffalo cows ranged between 424.02 to $596.65 \mathrm{~kg},-88.37$ to $120.01 \mathrm{~d},-4.93$ to $3.41 \mathrm{~d}$, -8.29 to $15.87 \mathrm{mo},-38.27$ to $58.31 \mathrm{~d}$ and -32.76 to $57.03 \mathrm{~d}$, respectively. In addition to breeding values for the aforementioned traits of buffalo dams were between -212.08 and $397.18 \mathrm{~kg},-53.39$ and $62.13 \mathrm{~d},-3.15$ and $4.83 \mathrm{~kg}, \quad-9.73$ and $10.90,-49.42$, and $79.33 \mathrm{~d}$ respectively. The ranges breeding values of buffalo cows were higher than those for sires and dams for FLMY, FLP, FLDM, and AFC but the highest value for FDO and FCI were in dams. Accuracy of portended breeding value variation between 69 to $94,0.37$ to 94 and 42 to $91 \%$ for sires, cows and dams, respectively, revealed that genetic improvement could be actualized through each of cows or sires or dams. High accuracy levels of breeding values help breeders to select for traits in their buffaloes and from now on genetic improvement in herds. The current results agreed with El-Awady et al. (2016) and El-Awady \& Abu El-Naser (2017). In Italian buffaloes, Catillo et al. (2001) reflected that the accuracy for AFC, CI and MY were $0.49,0.36$, and 0.49 , respectively. Additive and maternal genetic and permanent environmental trends are shown in Figure 1,2, 3, 4, 5 and 6. Generally, it is shown that direct and maternal genetic and permanent environmental trends for study traits fluctuated on years.

It is noticeable that the additive genetic value increased to $113.12 \mathrm{~kg}$ in year 1999 and decreased to $32.63 \mathrm{~kg}$ in year 2011 . While permanent environmental value increased to $57.6 \mathrm{~kg}$ in year 2014 and decreased to -79.10 in year 1992. It indicated that genetic programs and management can play an important role in the improvement of dairy buffaloes in Egypt. 
Abu El-Naser, IAM. Direct and maternal genetic trends for some productive and reproductive traits in Egyptian buffaloes

Table 4. Portended of breeding values for buffalo sires, buffalo cows and buffalo dams and accuracies\%, for studied traits

\begin{tabular}{|c|c|c|c|c|}
\hline \multirow{2}{*}{ Traits } & \multicolumn{4}{|c|}{ Breeding Values } \\
\hline & Minimum \pm SE & Maximum \pm SE & Accuracy, \% & Range \\
\hline \multicolumn{5}{|c|}{ Buffalo sires (EBV's) } \\
\hline FLMY & $-444.73 \pm 6.97$ & $397.84 \pm 7.35$ & $67-71$ & 842.57 \\
\hline FLP & $-27.52 \pm 1.18$ & $70.07 \pm 1.76$ & $74-89$ & 97.59 \\
\hline FLDM & $-3.78 \pm 0.60$ & $3.74 \pm 0.60$ & $94-94$ & 7.52 \\
\hline $\mathrm{AFC}$ & $-10.06 \pm 2.28$ & $13.76 \pm 2.58$ & $70-78$ & 23.82 \\
\hline FDO & $-44.54 \pm 1.70$ & $46.69 \pm 1.38$ & $70-81$ & 91.23 \\
\hline FCI & $-35.77 \pm 1.53$ & $46.40 \pm 1.29$ & $69-79$ & 82.17 \\
\hline \multicolumn{5}{|c|}{ Buffalo cows (EBV's) } \\
\hline FLMY & $-424.02 \pm 6.10$ & $596.65 \pm 5.90$ & $79-80$ & 1020.67 \\
\hline FLP & $-88.37 \pm 1.45$ & $120.01 \pm 1.42$ & $83-74$ & 208.38 \\
\hline FLDM & $-4.93 \pm 1.00$ & $3.41 \pm 1.05$ & $74-82$ & 8.34 \\
\hline $\mathrm{AFC}$ & $-8.29 \pm 1.27$ & $15.87 \pm 1.58$ & $90-94$ & 23.86 \\
\hline FDO & $-38.27 \pm 2.20$ & $58.31 \pm 2.01$ & $38-53$ & 96.58 \\
\hline FCI & $-32.76 \pm 1.98$ & $57.03 \pm 1.97$ & $37-39$ & 89.79 \\
\hline \multicolumn{5}{|c|}{ Buffalo dams (EBV's) } \\
\hline FLMY & $-212.08 \pm 8.21$ & $397.18 \pm 8.84$ & $45-59$ & 609.26 \\
\hline FLP & $-53.39 \pm 8.89$ & $62.13 \pm 2.32$ & $42-44$ & 115.52 \\
\hline FLDM & $-3.15 \pm 0.74$ & $4.83 \pm 0.74$ & $90-.91$ & 7.98 \\
\hline $\mathrm{AFC}$ & $-9.73 \pm 3.16$ & $10.90 \pm 3.16$ & $49-50$ & 20.63 \\
\hline FDO & $-49.42 \pm 1.66$ & $79.33 \pm 1.68$ & $70-71$ & 128.75 \\
\hline FCI & $-53.13 \pm 1.48$ & $106.01 \pm 1.45$ & $72-73$ & 159.14 \\
\hline
\end{tabular}

Table 5. Estimates of annual additive, maternal and environmental permanent trends for studied traits in Egyptian buffaloes

\begin{tabular}{lccc}
\hline \hline Traits & Additive & Maternal & Permanent \\
\hline FLMY & -0.749 & -0.052 & 2.24 \\
FLP & 0.039 & -0.104 & 0.061 \\
FLDM & -0.063 & -0.023 & 0.033 \\
AFC & -0.104 & 0.068 & -0.035 \\
FDO & -0.100 & -0.043 & 0.058 \\
FCI & -0.143 & -0.067 & 0.006 \\
\hline
\end{tabular}




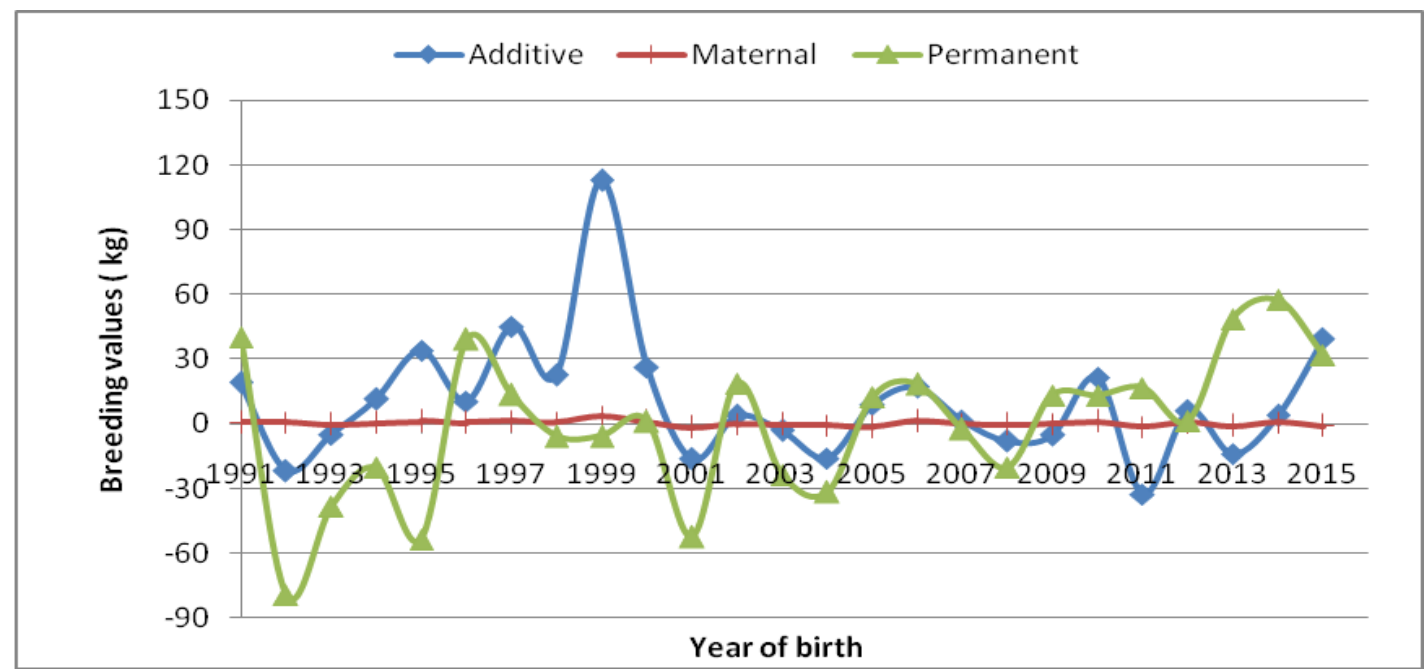

Figure 1. Additive and maternal genetic and permanent environmental for FLMY

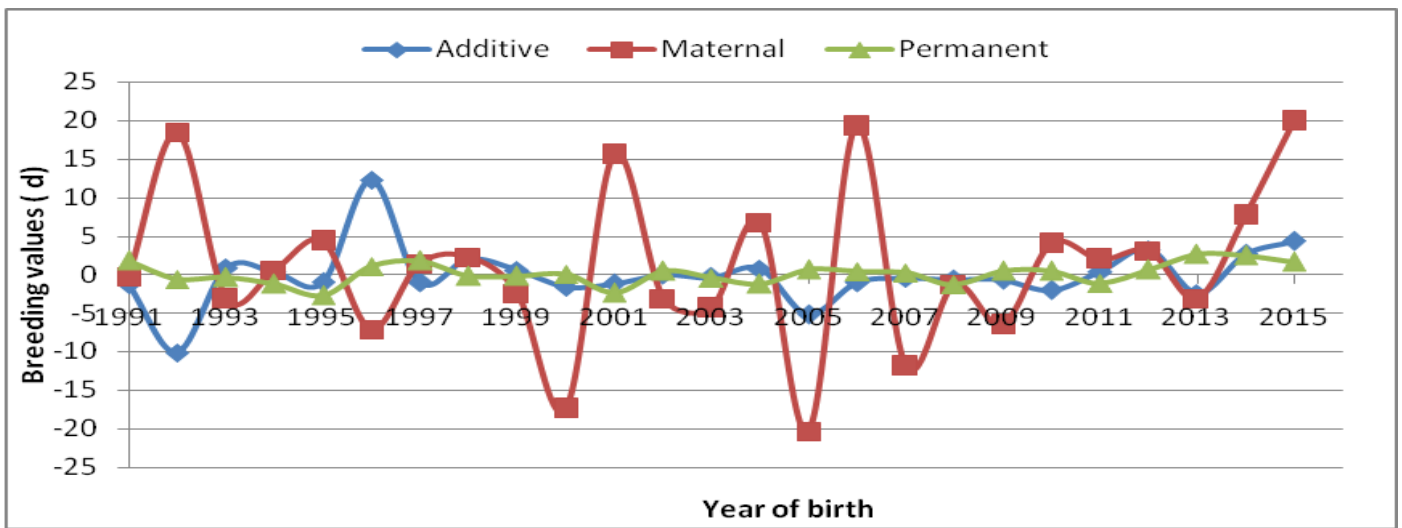

Figure 2. Additive and maternal genetic and permanent environmental for FLP

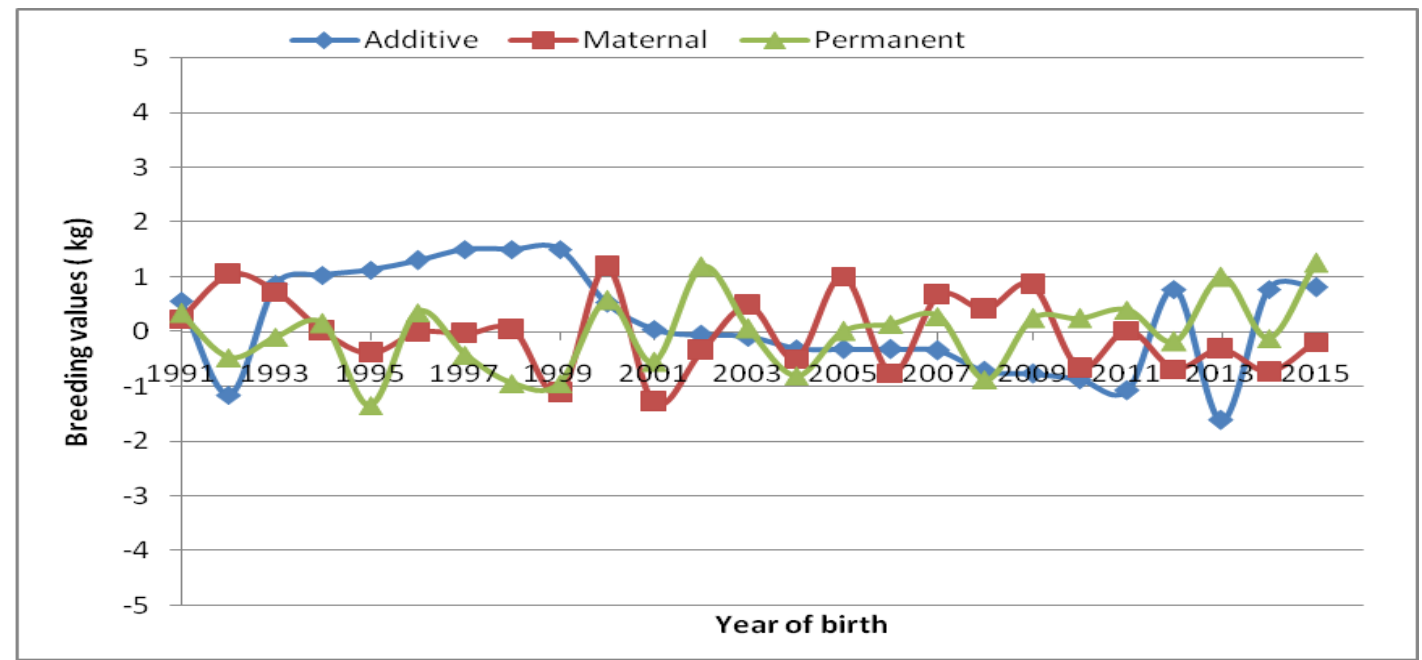

Figure 3. Additive and maternal genetic and permanent environmental for FLMD 


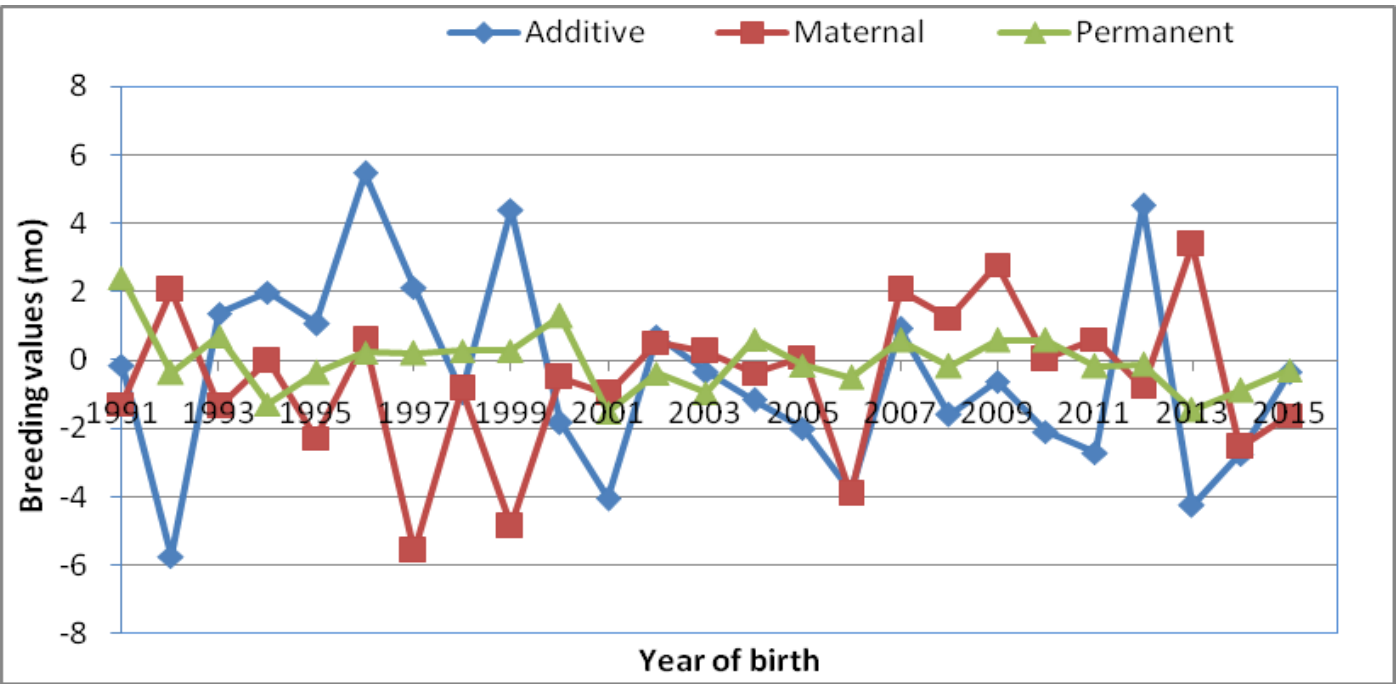

Figure 4. Additive and maternal genetic and permanent environmental for AFC

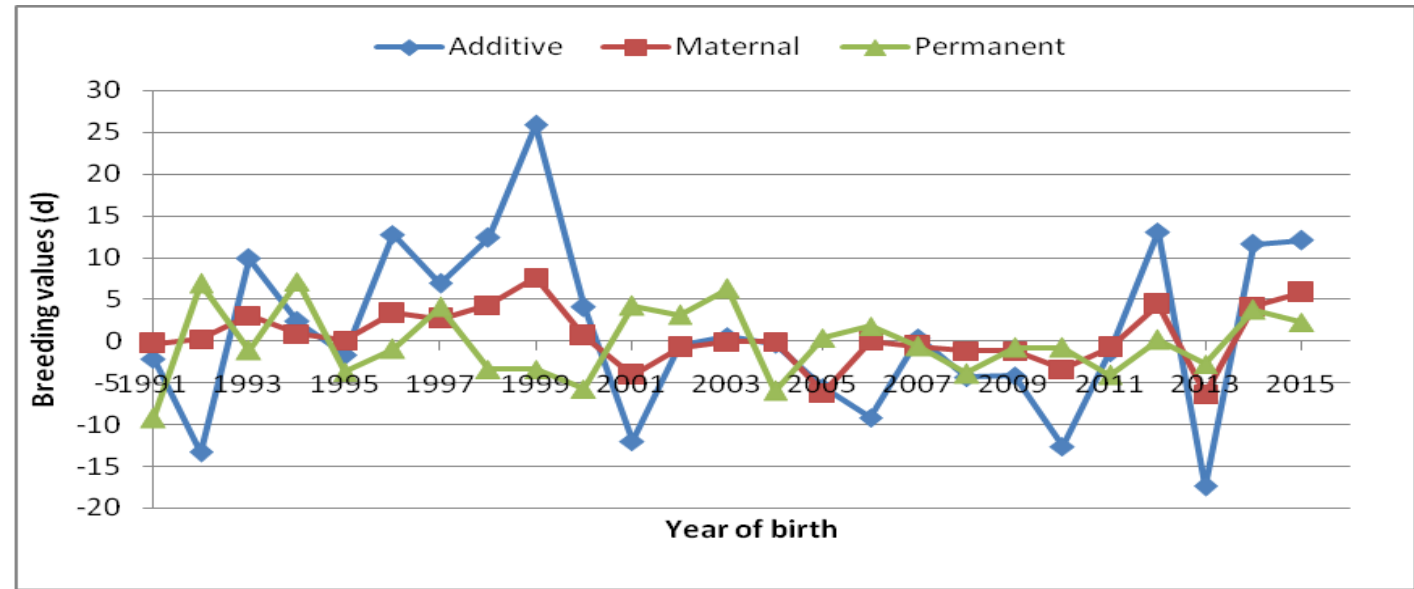

Figure 5. Additive and maternal genetic and permanent environmental for FCI

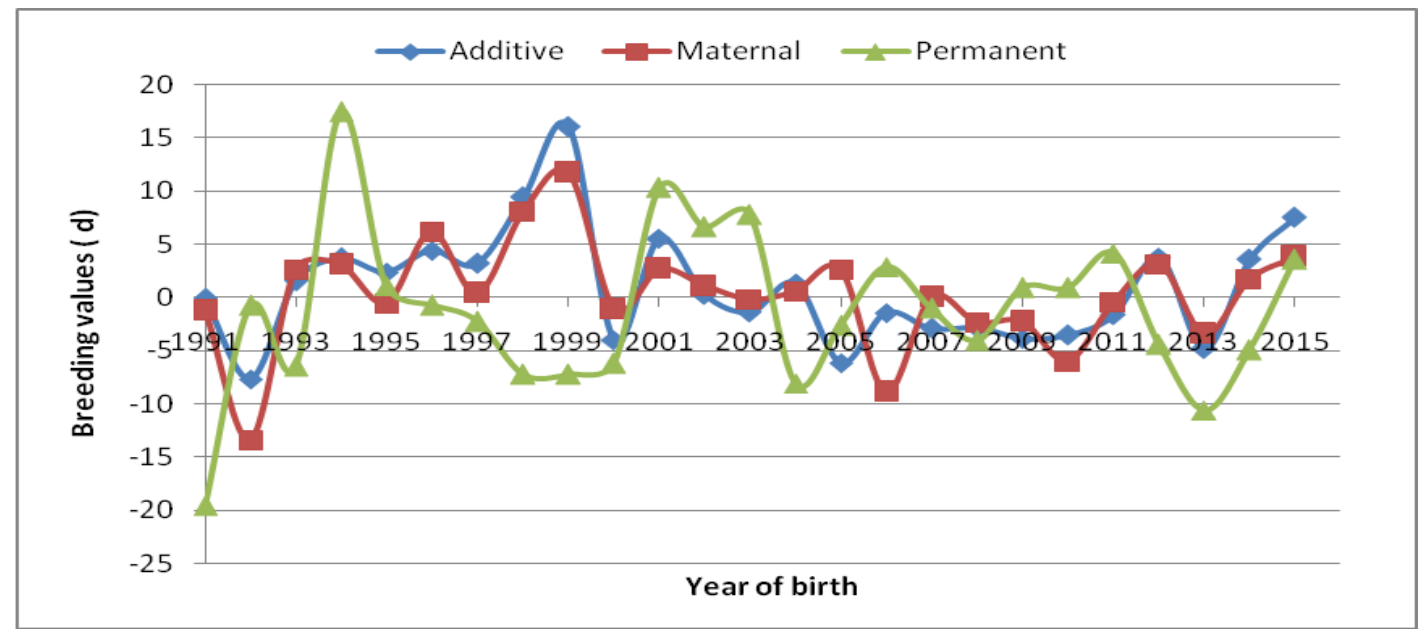

Figure 6. Additive and maternal genetic and permanent environmental for FDO 
Table 6: Estimates of annual phenotypic trends for studied traits in Egyptian buffaloes

\begin{tabular}{|c|c|c|c|c|c|c|}
\hline Year & FLMY, kg & FLP, d & FLDM, kg & $\mathrm{AFC}, \mathrm{mo}$ & FDO,d & FCI, d \\
\hline 1994 & 1621 & 196.8 & 8.2 & 45.9 & 106.2 & 418.6 \\
\hline 1995 & 1560 & 193.7 & 8.1 & 45.9 & 41.3 & 357.7 \\
\hline 1996 & 1686 & 205.0 & 8.5 & 28.5 & 157.5 & 496.0 \\
\hline 1997 & 1664 & 188.8 & 8.7 & 33.2 & 109.0 & 429.8 \\
\hline 1998 & 1414 & 169.5 & 8.6 & 45.7 & 124.8 & 421.8 \\
\hline 1999 & 1436 & 194.0 & 7.0 & 38.6 & 101.8 & 417.9 \\
\hline 2000 & 1588 & 196.1 & 7.9 & 42.0 & 124.6 & 426.6 \\
\hline 2001 & 1278 & 159.5 & 6.9 & 38.3 & 96.5 & 424.2 \\
\hline 2002 & 1614 & 192.4 & 8.3 & 41.4 & 152.6 & 449.1 \\
\hline 2003 & 1335 & 183.0 & 7.3 & 37.1 & 158.8 & 471.3 \\
\hline 2004 & 1622 & 189.2 & 8.4 & 35.3 & 118.2 & 416.5 \\
\hline 2005 & 1394 & 182.6 & 7.6 & 37.1 & 125.9 & 437.6 \\
\hline 2006 & 1431 & 180.8 & 7.7 & 38.7 & 130.8 & 435.1 \\
\hline 2007 & 1526 & 186.8 & 7.9 & 37.9 & 100.5 & 413.7 \\
\hline 2008 & 1687 & 202.7 & 8.1 & 37.5 & 122.6 & 429.2 \\
\hline 2009 & 1689 & 189.4 & 8.8 & 37.0 & 119.2 & 417.8 \\
\hline 2010 & 1542 & 185.3 & 7.9 & 37.1 & 97.3 & 413.4 \\
\hline 2011 & 1455 & 183.8 & 7.5 & 36.3 & 133.9 & 436.7 \\
\hline 2012 & 1475 & 186.9 & 7.6 & 36.6 & 132.6 & 442.4 \\
\hline 2013 & 1759 & 198.0 & 8.6 & 34.6 & 93.4 & 407.1 \\
\hline 2014 & 1766 & 204.5 & 8.4 & 46.4 & 91.5 & 395.1 \\
\hline 2015 & 1629 & 194.3 & 8.3 & 37.3 & 131.1 & 429.2 \\
\hline b-reg & 4.29 & 0.168 & 0.0022 & -0.122 & 0.343 & -0.313 \\
\hline
\end{tabular}

Similarly, noticed by El-Awady et al. (2017) for MY, LP, CI and DO in Friesian cows. The annual additive genetic trends for productive traits (FLMY, FLP, and FLMD) were non-significant and being $-0.749 \mathrm{~kg}, 0.03 \mathrm{~d}$ and $-0.063 \mathrm{~kg}$. Also annual additive trends even though negative for reproductive traits (AFC, FDO and FCI) were non-significant $-0.104 \mathrm{mo},-0.100 \mathrm{~d}$ and $-0.143 \mathrm{~d}$. Corresponding annual maternal genetic trends for productive and productive studied traits were nonsignificant and being $-0.05 \mathrm{~kg},-0.104 \mathrm{~d},-0.023 \mathrm{~kg}$, $0.068 \mathrm{mo},-0.043 \mathrm{~d}$ and $-0.067 \mathrm{~d}$, respectively. The reasons of this might be consulted to lock from animal selection or increased of culling of many preeminent buffaloes in previous years due to a greater age and ingress of many replacement heifers with less breeding value in the herd or using bulls don not have good breeding values for studied traits in insemination inside the farm. The present results similar to that reflected by Salem \& Hammoud (2016) for genetic trends of sires for FMY, FLP and FDO in Holstein were negative and non-significant and he added that may be attributed for selecting sires. The coefficient of permanent environmental trends for above mentioned traits were non-significant and positive expect $\mathrm{AFC}$ was negative $(2.24 \mathrm{~kg} / \mathrm{y}, 0.061 \mathrm{~d} / \mathrm{y}, 0.033 \mathrm{~kg} / \mathrm{y},-0.0 .35 \mathrm{mo} / \mathrm{y}, 0.058 \mathrm{~d} / \mathrm{y}$ and $0.006 \mathrm{~d} / \mathrm{y}$ ), respectively. It shows that the permanent 
environment had no clear effect on studied traits. That may be due to the animals in the farm was kept under control system environmental conditions and management and the betterment of the environmental conditions to desire to simplify selection programs.

Shalaby et al. (2016) obtained that the annual genetic tends for FLMY, FLP, FDO, and FCI were negative $-15.80 \mathrm{~kg},-6.55 \mathrm{~d},-5.658 \mathrm{~d}$ and $-5.801 \mathrm{~d}$, from 1972 to 2002 in Egyptian buffaloes. Fooda et al. (2010) found the annual genetic trends for milk yield in all Mahallet Mousa farms were positive and being $0.58 \mathrm{~kg}$ in Egyptian buffaloes. El-Arian et al. (2012) obtained that the annual genetic change for TMY and LP was positive and being $3.70 \mathrm{~kg}$ and $0.55 \mathrm{~d}$, respectively as the regression coefficient of sire breeding values per year in Egyptian buffaloes.

Annual phenotypic trends for studied traits in Egyptian buffaloes are illustrated in Table 6. Noticeable fluctuations were monitored for studied traits in different years. Corresponding estimation of annual phenotypic trends for FLMY, FLP, and FLDM were non-significant and positive. This probably refers to improvement partial in environmental conditions. Phenotypic trends for AFC and FCI were no significant and negative directions, pointing out declining trends in AFC and FCI. The alike phenotypic trend for FDO was non-significant, but positive, which is not desirable. Similarly, noticed by El-Arian et al. (2012) for MY, LP and DO in Friesian cows. In Egyptian buffaloes, Fooda et al. (2010) obtained the annual phenotypic trend for milk yield was $26 \mathrm{~kg}$ being in all Mahallet Mousa farms. El-Arian et al. (2012) obtained that the annual phenotypic trends for TMY and LP were highly significant and positive, (74.20 $\mathrm{kg}$ and $18.84 \mathrm{~d}$ ), respectively. Over and above, they added that phenotypic improvement in milk yield was carried out during the study and shown the variation in performance between years due to different of management, nutritional and climatic conditions during the period of study in Egyptian buffaloes.

\section{CONCLUSION}

The results indicate that the direct heritability estimate for studied traits was moderate. Therefore, the ability to increase the efficiency of those traits through genetic improvement and environmental conditions is needed on the farm at the same time. Additionally, increase and ranges accuracy estimated of breeding values for studied traits inferred being more genetic difference among individuals and increase the possible selection for those traits. Moreover, genetic, phenotypic and Environment values trends fluctuated over the year and non-significant for all studied traits. It is proved that designed genetic programs, management and environmental conditions not satisfactory during the period. It is shown that it is important to set up a plan to the improvement of genetic and environmental conditions in herd Egyptian buffaloes.

\section{ACKNOWLEDGEMENT}

High appreciation is delivered to all staff of Animal Production Research Institute (APRI), Ministry of Agriculture especially, all staff of Mahallet Mousa Experimental Farm for providing the data.

\section{REFERENCES}

Boldman K, Kriese L, Van Vleck L, Kachman, SD. 1995. A Manual for use of MTDFREML. A set for programs to obtain estimates of variances and covariance (DRAFT). New England (USA): Department of Agriculture, Agriculture Research Service, Clay Center.

Catillo G, Moioli B, Napolitano F. 2001. Estimation of Genetic Parameters of Some Productive and Reproductive Traits in Italian Buffalo. Genetic Evaluation with BLUP-Animal Model. AsianAustralasian J Anim Sci. 14:747-753.

El-Arian M, Shalaby N, Khattab A, Darwish S, Abou-Gamous R. 2012. Phenotypic and genetic trends for some milk yield traits of Egyptian buffaloes. J Anim Poult Prod. 3:353-364.

El-Awady H, Abd el-Khalek A, Abo Elreesh M. 2016. Genetic Evaluation for Some Productive and Reproductive Traits by Using Animal Model in A Commercial Friesian Herd in Egypt. J Anim Poult Prod. 7:279-285.

El-Awady H, Abu El-Naser IAM. 2017. Estimate of Direct and Maternal Genetic Parameters for some Production and Reproduction Traits in Friesian COWS through Sire and Animal Models. J Anim Poult Prod. 8:477-482.

El-Awady H, Salem A, Abdel-Glil M, Zahed S, Abo El-Enin A. 2017. Estimate of Genetic and Phenotypic Trends for Some Productive and Reproductive Traits of Friesian Cows in Egypt. J Anim Poult Prod. 8:329-344.

[FAO] Food and Agriculture Organization. 2013. FAO Statistical Yearbook. Rome (Italy): Food and Agriculture Organization of the United Nations.

Fooda T, Mourad KA, Gebreel I. 2010. Phenotypic and genetic trends for milk production in Egyptian buffaloes. J Am Sci. 6:143-147.

Gupta JP, Sachdeva GK, Gandhi R, Chakravarty A. 2015. Developing multiple-trait prediction models using growth and production traits in Murrah buffalo. Buffalo Bull. 34:347-355.

Liu Z, Jaitner J, Reinhardt F, Pasman E, Rensing S, Reents R. 2008. Genetic Evaluation of Fertility Traits of Dairy 
Cattle Using a Multiple-Trait Animal Model. J Dairy Sci. 91:4333-4343.

Madad M, Hossein-Zadeh NG, Shadparvar AA. 2013. Genetic and phenotypic parameters for productive traits in the first three lactations of Khuzestan buffaloes in Iran. Arch Anim Breed. 56:423-429.

Missanjo EM, Imbayarwo-Chikosi VE, Halimani TE. 2012. Genetic trends production and somatic cell count for Jersey cattle in Zimbabwe born from 1994 to 2005. Trop Anim Health Prod. 44:1921-1925.

Ramos A, Malhado C, Carneiro P, Gonçalves H, Azevedo D. 2006. Phenotypic and genetic characterization of the milk yield and calving interval in buffalo of the Murrah breed. Pesq agropec bras. 41:1261-1267.

Sahin A, Ulutas Z, Adkinson AY, Adkinson RW.2012 Genetic and environmental parameters and trends for milk production of Holstein cattle in Turkey. Ital J Anim Sci. 11:242-248.
Salem Mm, Hammoud M. 2016. Genetic aspects of some first lactation traits of Holstein cows in Egypt. Agyptian JAnim Prod. 53:75-80.

[SAS] Statistical Analysis System Institute. 2002. SAS/STAT User's Guide. (Ver 9). North Carolina (USA): Statistical Analysis System Institute Inc., Cary, NC, USA.

Seno L, Cardoso V, Faro L, Sesana R, Aspilcueta-borquis R, de Camargo G, Tonhati H. 2010. Genetic parameters for milk yield, age at first calving and interval between first and second calving in milk Murrah buffaloes. Livest Res Rural Dev. 22:1-8.

Shalaby N, Oudah E, El-Sharkawy Y. 2016. Comparison between some productive and reproductive traits and genetic parameters in the first three lactations in Egyptian buffaloes. J Anim Poult Prod. 7:113-119.

Thiruvenkadan A, Panneerselvam S, Murali N, Selvam S, Saravanakumar R. 2014. Milk production and reproduction performance of Murrah buffaloes of Tamil Nadu, India. Buffalo Bull. 33:291-300. 